\title{
Release Strategies of Telenomus Podisi for Control of Euschistus Heros: A Computational Modeling Approach
}

Igor Daniel Weber ( $\sim$ igorweberagr@gmail.com )

ESALQ-USP: Universidade de Sao Paulo Escola Superior de Agricultura Luiz de Queiroz https://orcid.org/0000-0002-5534-8587

Adriano Gomes Garcia

ESALQ-USP: Universidade de Sao Paulo Escola Superior de Agricultura Luiz de Queiroz

Adeney de Freitas Bueno

Embrapa: Empresa Brasileira de Pesquisa Agropecuaria

Regiane Cristina de Oliveira Freitas

UNESP: Universidade Estadual Paulista Julio de Mesquita Filho

Wesley Augusto Conde Godoy

ESALQ-USP: Universidade de Sao Paulo Escola Superior de Agricultura Luiz de Queiroz

\section{Research Article}

Keywords: Egg parasitoids, Biological control, Integrated Pest Management, Cellular automata

Posted Date: February 17th, 2022

DOI: https://doi.org/10.21203/rs.3.rs-1182644/v1

License: (c) (1) This work is licensed under a Creative Commons Attribution 4.0 International License.

Read Full License 


\section{Abstract}

The egg-parasitoid wasp Telenomus podisi has received attention as a biological-control agent for one of the most important soybean pests in Brazil, the stink bug Euschistus heros. As yet, no studies have conclusively established strategies for the release of $T$. podisi. We developed a computational model employing cellular automata to investigate release strategies for T. podisi in soybean crops, in order to optimize the use of these wasps in managing E. heros. A computational model was developed, using cellular automata in the $\mathrm{C}$ programming language and assuming a two-dimensional grid of cells corresponding to a soybean field. The biological dynamics of $E$. heros and T. podisi were programmed. The following parameters for release strategy were investigated: release mode, number of releases, number of parasitoids per hectare per release, and spacing between release points or strips. The sensitivities of the release and movement parameters were analyzed. The release strategies capable of maintaining an $E$. heros population below the Economic Threshold level involved releasing a total of at least 15,000 female parasitoids per hectare, in three or four releases of 5,000 or more. A 25-m spacing between release points or strips was indicated. The theoretical results produced by the computational model are expected to guide future field studies to improve T. podisi release plans for managing $E$. heros in soybeans.

\section{Introduction}

The brown stink bug Euschistus heros (Fabricius, 1974) (Heteroptera: Pentatomidae) is one of the most abundant insect pests of soybeans and other important crops in South America, mainly in central Brazil (Panizzi and Corrêa-Ferreira 1997). Its range extends from the relatively cool southern region to the warmer north and northeast regions, following the distribution of the soybean crop (Panizzi 2015). $E$. heros feeds directly on soybean pods, seriously affecting yields as well as the physiological and sanitary quality of the seeds (Corrêa-Ferreira and Azevedo 2002). To mitigate losses and increase profits, growers control the pest partly with phytophagous arthropods (Zalucki et al. 2009).

Chemical insecticides are the most common pest-control method adopted by soybean growers (Panizzi 2013). Although chemical products are still important for agriculture, its use without proper technical positioning can have undesired consequences, such as rapid selection of populations resistant to insecticides, pest resurgence, mortality and reduced performance of natural biological-control agents of the stink bug, environmental contamination, and increased production costs for farmers (Bueno et al. 2021). In addition, society's growing demand for food free of pesticide residues and produced more sustainably, and awareness of the harmful effects of pesticide abuse to the environment, is increasing interest in more-sustainable pest-management strategies.

Among the most sustainable management strategies, augmentative biological control is being adopted worldwide, increasing by 10 to $20 \%$ annually on more than 30 million hectares (van Lenteren et al. 2018). Egg parasitoids are the most important natural enemies used as biological-control agents of pentatomid stink bugs (Pacheco and Corrêa-Ferreira 2000). The parasitoid wasp Telenomus podisi Ashmead, 1893 
(Hymenoptera: Scelionidae) is most commonly used, due to its high parasitism capacity and control efficacy (Silva et al. 2018; Taguti et al. 2019; Bueno et al. 2020a). This wasp occurs from midwestern to extreme southern Brazil, i.e., is adaptable to a range of climates (Torres et al. 1997). Telenomus podisi parasitizes several host species including herbivores and predators (Moreira and Becker 1986; Medeiros et al. 1998; Margaría et al. 2009; Queiroz et al. 2017). Despite its polyphagous habit, in soybean crop its presence is strongly associated with the occurrence of E. heros (Pacheco and Corrêa-Ferreira 2000). Therefore, T. podisi has recently received significant attention as a biological-control agent for $E$. heros, and is presently used in inundative releases on approximately 20,000 hectares of soybeans in South America (Bueno et al. 2020b).

The use of T. podisi as a biological-control agent in agriculture must be based on detailed knowledge of the biology and ecological relationships among this parasitoid, its host, and the environment (Yeargan 1982; Nakama and Foerster 2001; Peres and Corrêa-Ferreira 2004; Silva et al. 2008; Rocha 2016; Lahiri et al. 2017; Silva et al. 2018). However, few studies have established effective release strategies for T. podisi for biological control of E. heros. Most recently, Bueno et al. (2020a) evaluated the efficiency of two release techniques and different application times for the parasitoid in suppressing $E$. heros populations, in comparison to control by chemical insecticides. However, different numbers of released parasitoids and various release frequencies over the crop season still need to be tested. The process of determining these variables of parasitoid release for pest suppression can be time-consuming and costly, as it is often carried out by trial and error. Furthermore, it is essential to determine the spacing of release (spatial distance between release points), in addition to the need to repeat these studies in different crop seasons and farms, to increase experimental precision and generalization (Pomari et al. 2013; Bueno et al. 2020a). Computational models can help to guide parasitoid release studies, indicating which are the most promising strategies to test in the field, based on the theoretical results produced by the model. Use of a model can reduce the experimental and financial effort and accelerate the development and implementation of management tactics for producers (Plouvier and Wajnberg 2018).

Cellular automata (CA) are suitable for developing these ecological models since they represent the presence or absence of different developmental stages of the parasitoids and stink bugs. The spatial distribution of organisms in CA is described by a two-dimensional grid of cells, whose states may vary over time steps, according to simple stochastic rules that mimic the biological dynamics of these insects (Hiebeler 2005; Garcia et al. 2014). This approach can explicitly represent foraging by T. podisi adults for E. heros eggs, allowing a study of the spatial configurations of parasitoid releases and its effect on the efficiency of suppressing the stink-bug population. Combining this modeling method with individualbased modeling (which focuses on the variability of the individual characteristics of the agents represented in the model so that population behavior emerges from interactions between individuals) can realistically represent the movement and host-parasitoid relationship, producing helpful and reliable insights for the study of parasitoid release strategies.

Previous individual-based models have focused on understanding the importance of biological and behavioral-ecology aspects of the host-parasitoid relationship (e.g., fecundity, longevity, attack rate, 
competition, parasitoid dispersal capacity, parasitoid release density) to guide studies to prospect for natural enemies and to optimize biological-control practices (Van Roermund et al. 1997; Wajnberg et al. 2016; Plouvier and Wajnberg 2018). However, researchers have insufficiently explored computational models as an applied approach to study release strategies to optimize the use of parasitoids in the field. The development of a computational model to evaluate different parasitoid release strategies can guide further field research to implement $T$. podisi release strategies. This study aimed to develop a computational model using cellular automata to investigate T. podisi release strategies in soybean crops, in order to optimize its use in suppressing populations of $E$. heros. This model may help to increase the efficiency of this parasitoid in controling E. heros in soybean, especially in South America and wherever else this pest occurs.

\section{Material And Methods}

\section{Computational modeling}

A computational model was developed for the cellular automata approach, using the $\mathrm{C}$ programming language. A two-dimensional grid (lattice) of $204 \times 204$ cells was created, corresponding to a soybean field, large enough to prevent insects from reaching the lattice edges during simulations. Four rows and columns $(i=\{1,2,203,204\}$ and $j=\{1,2,203,204\})$ were used as fixed edges throughout the simulation, resulting in an area available for insects of $200 \times 200$ cells, representing 4 hectares of soybean cultivation. Each cell corresponds to $1 \mathrm{~m}^{2}$ containing approximately 30 soybean plants, totaling 300,000 plants per hectare, a density routinely used on Brazilian farms (Balbinot Junior et al. 2015). Each cell can be occupied by multiple insect life stages simultaneously. It was assumed that the study of the dynamics of the stink bug and the parasitoid populations took place between the early reproductive stage (soybean development stage $\mathrm{R}_{1}$ ), when $E$. heros usually starts to colonize an area, until the crop ripens and the stink bugs disperse to alternative host plants (Bortolotto et al. 2015), corresponding to a period of approximately 80 days. Therefore, each simulation had 80 time steps $(\mathrm{t})$, each step equivalent to one day. The dynamics of crop ripening were not represented in the model, assuming that the soybean plants in each cell were at the appropriate size to receive populations of $E$. heros and provide unlimited food throughout the simulation.

\section{Population dynamics of Euschistus heros}

Three developmental stages of E. heros were represented separately in the model: egg, nymph, and adult. In the nymph and adult stages, only female populations were considered, as they produce the eggs and offspring. At the beginning of each time step, adults and nymphs had probabilistic determinant values of death according to the equation proposed by Garcia et al. (2014):

$$
M(s)=1-\sqrt[d]{v_{s}}
$$


where $M(s)$ is the daily probability of death of the developmental stage (s), $d$ is the duration of the developmental stage, and $v_{s}$ is its viability (Table 1 ). Adult mortality was defined based on the viability of individuals until the end of their fertile period. 
Table 1

Parameter values used in the model and their respective literature sources.

\section{Parameters}

Telenomus podisi

Fertile period viability

Immature stage viability

Immature stage duration

Fertile period

Maximum longevity

Sex ratio

Oviposition curve

Dispersal and foraging radius

Euschistus heros

Fertile period viability

Nymph viability

Egg viability

Nymph stage duration

Embryo stage duration

Age of onset of nymph dispersal

Sexual maturity

Fertile period

Maximum longevity

Sex ratio

Oviposition probability

Mean total number of egg masses per female

Mean total number of eggs per female

Mean number of eggs per egg mass
Value

Reference $^{1}$

\begin{tabular}{ll}
$23.33 \%$ & 9 \\
\hline $82.42 \%$ & 9 \\
\hline 14.70 days & 9 \\
\hline 25 days & - \\
\hline 26 days & 9 \\
\hline 0.70 & 2 \\
\hline Equation $(2)$ & 8 \\
\hline $8 \mathrm{~m}$ & 7 \\
\hline
\end{tabular}




\section{Parameters}

Exponent $k_{n}$ of nymph aggregation

Exponent $k_{a}$ of adult aggregation

Mean daily dispersal of nymphs and adults

11 - Azambuja et al. (2013); 2 - Castellanos et al. (2019); 3 - Costa et al. (1998); 4 - Mendoza et al. (2016); 5 - Michereff et al. (2019); 6 - Possebom et al. (2020); 7 - Ramos (2020); 8 - Rocha (2016); 9 - Silva et al. (2018); 10 - Souza et al. (2018).

Nymphs from the second instar (over five days of age) and adults can move within a radius of $3 \mathrm{~m}$ or remain still. The movement was established according to probabilities established by the negative binomial distribution, with values of nymphal aggregation exponents $\left(k_{n}\right)$ and adults $\left(k_{a}\right)$ equal to 2.8433 and 3.1728 ( $2<k<8$ indicates moderate aggregation), respectively, according to the results obtained by Souza et al. (2018). The value of the mean daily dispersal estimated for the negative binomial distribution was assumed to be $0.5 \mathrm{~m}$ for both stages of development, since pentatomids move very little when they find food (Panizzi et al. 1980; Souza et al. 2013). Each individual can move to any neighboring cell as long as there is space available, according to the support capacity $K$ for the respective stage of development. The support capacity of the system was represented by the maximum number of egg masses, nymphs, and adults capable of occupying the same plant, so that, when reached, it was not possible for new individuals of the respective development stage to enter until a space was freed. The carrying capacities of nymphs $\left(K_{n}=500\right)$ and adults $\left(K_{a}=300\right)$ of stink bugs were defined based on the total number of eggs supported by a cell lattice and from preliminary tests, in order to determine the highest values that will not limit the growth of the stink-bug population, but low enough to reduce the computational effort of the model.

After moving, each sexually mature female ( $\geq 13$ days after emergence) has a $70 \%$ daily probability of ovipositing in the Moore neighborhood of $3 \times 3$ cells, at each time step, ovipositing a mass of 11 eggs (Possebom et al. 2020). Each cell in the network can hold up to 60 egg masses $\left(K_{0}\right)$, equivalent to two egg masses per plant. A fertile period of 24 days was assumed for females (Azambuja et al. 2013; Michereff et al. 2019), and after this age, they no longer oviposit and are removed from the simulation. Therefore, the maximum longevity attributed to a female of $E$. heros is 36 time steps (days) after its emergence. Over this period, each female can oviposit a mean of 13 egg masses, totaling 143 eggs, resembling the mean numbers observed by Possebom et al. (2020) in a study of the biology of E. heros.

All eggs of one egg mass have the same age. An embryonic period of 5 days was assumed, when nonviable eggs (approximately 37.10\%) and those that would give rise to male individuals (assuming a sex ratio of 0.5) were eliminated (Azambuja et al. 2013; Mendoza et al. 2016; Michereff et al. 2019). Female nymphs hatch from the remaining eggs and 30 days later give rise to female adults, restarting the stinkbug development cycle. 


\section{Population dynamics of Telenomus podisi}

The population dynamics of T. podisi described in the model considered two life stages, immature (egg, larva, and pupa stages) and adult (only females). At each time step, adults had probabilities of dying determined by Equation (1), according to its respective parameters (Table 1). Adult viability was defined based on the study by Silva et al. (2018).

Only adults were able to move, as the immature stage of the parasitoid takes place inside the eggs of its host. The movement mechanism of $T$. podisi females in the model is directly associated with foraging for stink-bug eggs to parasitize. It was assumed that females can direct their movement toward cells containing available $E$. heros eggs, considering a maximum dispersal radius of eight meters (Ramos 2020). Thus, at each time step, each female searches within a radius of eight meters around her current position for one cell with non-parasitized stink-bug eggs to which they can move and lay eggs if this cell has space available for the parasitoid (with $K_{t}$ carrying capacity available for adult parasitoids). Each female is able to move to only one cell in each time step. When no $E$. heros egg cells are found within the daily dispersal radius, the females move randomly to one of the cells within this radius. The carrying capacity of $T$. podisi females $\left(K_{t}=550\right)$ was defined based on the total number of parasitoid immatures carried by a cell, which is equivalent to the carrying capacity of stink-bug eggs, and from preliminary tests following the same criteria as before for stink-bug carrying capacity.

We assumed that female wasps only begin to oviposit on the day after emergence. After moving, each female can parasitize a limited number of stink-bug eggs per day in the Moore neighborhood of $3 \times 3$ cells, depending on the age of the adult, according to the equation estimated from the data of Rocha (2016):

$$
\left\{\begin{array}{c}
\theta(i)=13.62737+e^{(-0.10221 i)}, \text { if } i \leq 25 \\
\theta(i)=0, \text { if } i>25 .
\end{array}\right.
$$

where $\theta(i)$ is the number of eggs the parasitoid can lay in the time step, and $i$ is its current age minus one day (referring to the pre-oviposition period). Each parasitoid female lays only one egg per host egg. A fertile period of 25 days was assumed, since the number of eggs laid daily by each female after this period is less than 1, according to the estimated Equation (2). Telenomus podisi females are removed from the model when they reach 26 days after emergence. All parasitized $E$. heros eggs were considered to be non-viable, even if the immature stage of the parasitoid did not complete its development.

The age of each T. podisi immature from the same parasitized $E$. heros egg mass corresponds to the mean of all the parasitoid ages of this egg mass. When immatures reach the age of 14 time steps (days), non-viable immatures (approximately 17.57\%) and those that would give rise to male adults are eliminated (according to a sex ratio of 0.7) (Castellanos et al. 2019), and females emerge. The computational model developed is available in the Online Resource 1.

\section{Simulations}




\section{Telenomus podisi release strategy}

This simulation aimed to evaluate the efficiency of different T. podisi release strategies in suppressing an E. heros population. Strategies varied according to four parameters: release mode (in strips and at points), number of releases over time steps (1,2,3, or 4 releases), number of female parasitoids per release $(3,000,5,000,7,000$, or 10,000 parasitoids per hectare) and the spacing between releasing strips or points $(5,10,25$, or $50 \mathrm{~m}$, corresponding to $20,10,4$, and 2 strips per hectare or $400,100,16$, and 4 points per hectare, respectively) (Figure 1A). These values of release parameters were established based on the reference specification for the use of T. podisi (Brasil 2019), which recommends three releases of 6,500 adults (male and female) per hectare, at intervals of 7 days, distributed at 32 equidistant points per hectare (space between points of approximately $18 \mathrm{~m}$ ). Therefore, 2 (release mode) $\times 4$ (number of releases) $\times 4$ (number of female parasitoids per release) $\times 4$ (spacing between releasing strips or points) $=128$ different $T$. podisi release strategies simulated, in addition to the control (without release), with 15 repetitions for each scenario.

The cell grid was randomly colonized by adult stink bugs in the $80 \times 80$ central cells at the beginning of the simulation (Figure 1B). We performed a colonization of 8,000 adult females between 1 and 13 days of age, i.e., the age at which they reach sexual maturity and start oviposition (Azambuja et al. 2013; Michereff et al. 2019; Possebom et al. 2020), over the first 10 time steps (800 females released per time step), simulating the arrival of stink bugs in the crop. This grid colonization configuration was established based on previous tests, in order to establish a significant pest infestation and make stinkbug eggs available throughout the simulation time steps but minimizing the computational effort, besides preventing insects from reaching the fixed edge of the grid of cells. The releases of the parasitoids were implemented based on the area of $100 \times 100$ central cells of the lattice (representing one hectare of the crop field), in order to cover the area of occupation of the stink bugs (Figure 1B). The parasitoid releases started on the fifth day after colonization by $E$. heros, and the other releases, when performed (based on the simulated release strategy), occurred at intervals of seven days (Brasil 2019).

The simulations were carried out assuming two configurations of the biological dynamics of T. podisi, separately. The first configuration assumed that the parasitoid's offspring developed and adults successfully emerged, while the second configuration assumed that the offspring of the parasitoids were eliminated when they emerged. This second configuration aimed to evaluate the parasitoids released under different strategies (which resembles control by chemical insecticides) since the first configuration does not allow a clear assessment of the effect of the release strategies, due to the large increase in parasitoids (for more details see the Results section).

Model sensitivity

The sensitivity analysis assessed the importance of each T. podisi release parameter for efficiency in suppressing the $E$. heros population, according to the model. The values of three of the four release parameters were fixed (according to the following arbitrarily defined base values: release in strips, two releases, 7,000 parasitoids per release, and 25-m spacing between strips); and the value of the remaining 
parameter was varied; and the effect on the population of $E$. heros along the time steps was evaluated. We performed 15 repetitions. For the release mode parameter, the release in strips was compared with the release at points, while the other parameters were kept fixed according to the selected base scenario. For the parameter number of releases, the model's responses were evaluated for 1 and 4 releases. For the number of parasitoids per release, releases of 3,000 and 10,000 parasitoids were compared; and for the spacing between strips, spacings of $5 \mathrm{~m}$ are $50 \mathrm{~m}$ were compared, always considering the other parameters of the base scenario. Grid colonization by stink bugs was configured as described above, taking into account the dynamics of the parasitoids, in which the offspring are eliminated as the adults emerge.

The sensitivity of the model to variations in the dispersal capacity of adult and immature stages of $E$. heros, and of adult stage of T. podisi on the stink-bug population over time was evaluated. The value of the daily mean dispersal of immature and adults of $E$. heros was varied between 0.25 and $1.0 \mathrm{~m}$, and the value of the dispersal radius of $T$. podisi between 4 and $16 \mathrm{~m}$. The base configuration of parasitoid release, the grid colonization, and the configuration of the parasitoid dynamics were the same as described above. As greater dispersal was simulated for both species, a lattice of $254 \times 254$ cells was assumed to prevent insects from reaching the edges. We performed 15 repetitions.

\section{Data analysis}

We produced data for the total number of eggs, nymphs, and adults of $E$. heros and the immatures and adults of T. podisi over the 80 time steps of each simulation. Evaluations and analyses were carried out based on a number of stink bugs greater than or equal to $0.5 \mathrm{~cm}$ per cell of the egg parasitoid release area $(100 \times 100$ central cells), to evaluate the release strategies and simulations that contributed to maintaining the stink-bug population below the established Economic Threshold (ET) in soybean, of 2 stink bugs ( $\geq 0.5 \mathrm{~cm}$ or from the third instar) per linear meter (Bueno et al. 2015), equivalent to 2 female stink bugs (nymphs $>12$ days old and adults) per cell $\left(\mathrm{m}^{2}\right)$.

The hierarchical clustering technique was used to identify similarities among the 128 release strategies of T. podisi plus the control, based on standardized data for the mean number of stink bugs $(\geq 0.5 \mathrm{~cm})$ per cell of each strategy in the last time step. The dissimilarity matrix was calculated using the Euclidean method, and the hierarchical clustering was performed using the Ward (1963) minimum variance method, which showed the higher clustering coefficient value (0.9943; values closer to one indicate a strong clustering structure). All analyses were performed using the R software (R Development Core Team 2021).

\section{Results}

\section{Release strategies}

When stink bugs are not managed (control treatment), the population grows exponentially until the end of the simulation, when it reaches an mean ( \pm standard error) of $39.37( \pm 0.13)$ stink bugs $(\geq 0.5 \mathrm{~cm})$ per 
cell or square meter (Figure 2A). This is about 18.2 times above the established ET ( 2 stink bugs $\geq 0.5$ $\mathrm{cm} /$ meter), exceeded in the 26th time step after the arrival of stink bugs in the grid. The number of $E$. heros eggs, nymphs, and adults showed delayed peaks from each other, resulting from the biological dynamics of these stages. Peaks of eggs precede the peaks of nymphs as they hatch, and the adult peak when the nymphs emerge, which in turn oviposit, producing a new peak of eggs higher than the previous one. Then, the cycle restarts again (Figure 2B). Note that in this model, all development stages can occur simultaneously in the same time step. The highest population (mean \pm standard error) reached by stink bugs in the simulations was $2,597,177.00( \pm 9,495.64)$ eggs, $1,618,390.80( \pm 4,784.84)$ nymphs, and $101,525.67( \pm 348.62)$ adults, in time steps 78,79 and 66 , respectively.

All T. podisi release strategies carried out helped to reduce the stink-bug population below the ET at the end of the crop cycle, when the offspring of the released parasitoids could emerge and also suppress the stink-bug population (Figures 3 and 4). However, when only one release of 3,000 or 5,000 parasitoids was performed, the $E$. heros population still exceeded the ET during the crop cycle for all release spacings between points (Figure 3) and strips (Figure 4). A release of 3,000 female parasitoids per hectare did not manage the stink-bug population. In addition, the release strategies of 5,000 parasitoids per release spaced $50 \mathrm{~m}$ between points proved less efficient in suppressing the stink-bug population compared to other spacings (Figure 3).

Considering only the action of the released parasitoids, in which the offspring were eliminated when emerging, clearer differences appeared between the release strategies, especially regarding the number of releases (Figures 5 and 6). Only three or four parasitoid releases were able to prevent the stink-bug population from growing above the ET, except for the lowest number of 3,000 parasitoids per hectare, which was not able to maintain the number of stink bugs below ET even after four releases. Three releases of 5,000 parasitoids per hectare per release at points spaced $50 \mathrm{~m}$ apart still allowed the stinkbug population to increase above the ET (Figure 5), which was not observed for strip releases (Figure 6).

The dendrogram of the hierarchical cluster analysis (Figure 7) indicated six large groups, taking into account the height equal to 2 . The two groups on the right showed little difference from the control (third group from the right). These two groups correspond to the release strategies that resulted in the highest mean numbers of stink bugs $(\geq 0.5 \mathrm{~cm}$ ) per cell at the end of the simulations (Figure 7, row a). The three groups from the right, which are also the least efficient in suppressing the stink-bug population, mostly composed used only one parasitoid release throughout the entire simulation. In contrast, the best group, indicated by the red rectangle in Figure 7, was composed of the most efficient T. podisi release strategies for stink-bug management, which kept the pest population below ET. These best strategies used the largest numbers of total parasitoids released (Figure 7, row b), with three and four releases (Figure 7, row c) with at least 5,000 parasitoids per release (Figure 7, row d). It was not possible to identify a clear pattern of clustering the strategies regarding spacing and release mode of the parasitoids (Figure 7, rows e and $\mathrm{f}$, respectively), as observed for the other factors. 
There is an asymptotic tendency toward reduction of the stink-bug population $(\geq 0.5 \mathrm{~cm})$ as the total number of released parasitoids (product of the number of releases by the number of parasitoids per hectare per release) increases, according to their release strategies (Figure 8). Thus, it appears that releases of a total of 20,000 or 40,0000 parasitoids do not differ significantly in their efficiency in suppressing an E. heros population, for the conditions considered in the model, although the first strategy is financially more advantageous. Nevertheless, different strategies with similar numbers of total released parasitoids differed significantly in their ability to control the stink-bug population, highlighting the importance of the configuration of the release factors to establish efficient strategies. In addition, spacings of 5,10 , and $25 \mathrm{~m}$ between points or strips have very similar efficiencies, compared to the 50-m spacing for most of the strategies evaluated (means and respective standard errors are provided in Online Resource 2, Table S1).

\section{Model sensitivity}

The sensitivity of the model to variations in the values of $T$. podisi release parameters, analyzed by the variation in the number of stink bugs $(\geq 0.5 \mathrm{~cm})$ per cell throughout the soybean cycle, is shown in Figure 9. The model is not very sensitive to variation of the parasitoid release mode (red and blue lines correspond to the release in points and strips, respectively), for the configuration of two releases of 7,000 parasitoids with a spacing of $25 \mathrm{~m}$. Similarly, the variation in spacing values (red and blue lines refer to spacings of 5 and $50 \mathrm{~m}$ between release strips, respectively) had little influence on the model's response, that is, on the suppression exerted by the parasitoids at the values tested. On the other hand, the model was very sensitive to the variation in the number of parasitoids per release (red and blue lines correspond to 3,000 and 10,000 parasitoids, respectively) and in the number of releases performed (red and blue lines correspond to 1 and 4 releases, respectively), indicating that these are important parameters to determine efficient strategies to release egg parasitoids for the management of stink bugs.

Regarding the dispersal parameters of parasitoids and hosts, the model was more sensitive to the dispersal capacity of T. podisi (Figure 10, red and blue lines correspond to dispersal radii of 16 and $4 \mathrm{~m}$, respectively) compared to the dispersal capacity of nymphs and adults of $E$. heros (red and blue lines correspond to dispersal capacities of 1.0 and $0.25 \mathrm{~m}$, respectively, for these stages), for the range of values considered in the analysis. The model was similarly sensitive to dispersal of stink-bug nymphs and adults. In addition, the simulations with higher dispersal values of the nymphs and adults showed smaller populations of stink bugs, possibly because the higher dispersal increased the meeting ratio of the parasitoids and the eggs of the stink bug.

\section{Discussion}

The results of this computational model provided important information to improve recommendations about releases of $T$. podisi to manage $E$. heros in soybean fields. Overall, our results indicated that $T$. podisi has high potential as a biological-control agent for use in augmentative biological-control programs and can be used successfully against $E$. heros. Successful results of egg-parasitoid releases have also been reported for other scelionid species. For example, mass releases of Trissolcus basalis 
(Wollaston 1858) (Hymenoptera: Scelionidae) in soybean fields resulted in significant increases in parasitism of eggs of Nezara viridula (Linnaeus, 1758) (Hemiptera: Pentatomidae) (Thomas 1972, Lee 1979). Years later, T. basalis was also reported as successful in an augmentative biological-control program to control N. viridula in Brazil, adopted in the 1980s and 1990s in soybean fields (Corrêa-Ferreira 2002). More recently, Bueno et al. (2020a) reported $70 \%$ parasitism of $E$. heros eggs after three consecutive releases of $T$. podisi weekly, using pupae released in capsules or in bulk.

Despite those promising results, currently, stink bugs in soybeans are still controlled primarily through insecticide applications (Bueno et al. 2021), which can be harmful to parasitoids and other biologicalcontrol agents (Torres and Bueno 2018). However, comparing the results of simulations in which the emergence of the released parasitoid offspring was considered with those in which the offspring were not considered illustrated the importance of preserving biological-control agents, maintaining favorable environmental conditions for the survival and development of populations of these agents for moreefficient management of the pest insect. These conditions can only exist with a more sustainable pestmanagement system, Integrated Pest Management (IPM) (Bueno et al. 2021). Using chemical insecticides selective to natural enemies (Torres and Bueno 2018), reducing the number of pesticide applications with the use of ETs (Bueno et al. 2013), diversification of pest-control strategies, and conserving nutritional resources for parasitoid adults (i.e., nectariferous plants close to the crop) can preserve biological-control agents (Tillman et al. 2015; Pazini et al. 2019) and reduce the use of insecticides in soybean IPM (Bueno et al. 2021). Thus, in a favorable environment for survival of the offspring of released parasitoids (simulations that considered the offspring of the released parasitoids), carrying out just one release of 7,000 females of $T$. podisi or two releases of 3,000 females of the parasitoid may be enough to maintain the $E$. heros population below the ET throughout the entire soybean cycle, according to the conditions assumed in our simulations.

There was no significant difference between strategies with more than one release of 5,000 or more females when considering the offspring of the released parasitoids, due to the large population growth of these parasitoids during the simulation, since the parasitoid development cycle is faster than the $E$. heros cycle (Chevarria et al. 2013). In these strategies, the parasitism capacity of the T. podisi population exceeds the number of eggs laid by the stink bugs, extinguishing the pest population during the simulation. Thus, from a theoretical perspective, the limiting factor differentiating the efficiency of the parasitoid release strategies in the model was the size of the stink-bug population assumed for the simulations (for the configuration in which the parasitoid offspring are not eliminated at emergence), which in turn depends on the initial number of adults that colonize the grid. However, since the simulation results only reflect the action of the parasitoids effectively released in the crop, we decided to study release strategies based on simulations in which the offspring of the parasitoids are eliminated from the model upon emergence.

The release strategies capable of maintaining the stink-bug population below the ET were those that released at least 15,000 female adults of $T$. podisi per hectare in total (considering all releases), based on the simulations in which the offspring of the parasitoids were not considered. However, the way that 
these parasitoids are released throughout the crop cycle is essential for successful management. For example, two releases of 10,000 females per hectare, totaling 20,000 females, were less efficient in suppressing the stink-bug population than three releases of 5,000 females, totaling 15,000 females per hectare. The importance of the number of releases and the number of parasitoids per release to the efficiency of the release strategy can be better observed in the sensitivity analysis. This clearly indicates a field scenario in which the number (density) of released insects and the pest density are among the most important variables that affect the parasitism and field efficiency of egg parasitoids in augmentative biological-control programs (Parra 2014). The greater longevity of $E$. heros females and their constant migration from neighboring areas (not considered in this model) allows the stink bugs to oviposit longer than the period of significant parasitism of the T. podisi population from a single release. Thus, the higher efficiency of release strategies that distribute the parasitoids in three or four releases can be explained by the successive supply of young T. podisi females - which have the highest parasitism capacity in the first days after emergence (Rocha 2016; Silva et al. 2018) - during the first population peak of E. heros eggs. Furthermore, it is important to balance the number of parasitoids per release so that the daily parasitism capacity of the released population does not excessively exceed the population of stink-bug eggs available for parasitism. Therefore, conducting more releases (in order to cover the first peak of $E$. heros oviposition) with fewer parasitoids in each release (depending on the level of infestation by the pest) can more efficiently use the parasitoids released by allowing the parasitism capacity of this population to more closely approximate the number of host eggs available for parasitism. Therefore, for future field release studies with $T$. podisi, it is recommended to test strategies with three or four releases with 5,000 or more females per hectare, since the other strategies were not capable of maintaining the $E$. heros population below the ET, for the level of stink-bug infestation assumed in the model. This recommendation is similar to that indicated in the reference specification for the use of T. podisi in Brazil (Brasil 2019), which suggests three releases of approximately 4,550 female parasitoids per hectare (assuming a sex ratio of 0.7 ). Bueno et al. (2020a) achieved satisfactory control of an E. heros population when they performed three releases of 6,250 T. podisi pupae (approximately 4,375 females, assuming a sex ratio of 0.7) at seven-day intervals. Sá et al. (1993) concluded that higher efficiency in the management of Helicoverpa zea (Boddie, 1850) (Lepidoptera, Noctuidae) in maize with the egg parasitoid Trichogramma pretiosum Riley, 1879 (Hymenoptera: Trichogrammatidae) is achieved with three or more releases spaced 4 to 7 days apart, similar to the recommended strategies for T. podisi based on the model.

From an economic perspective, the best release strategies are those that maintain the stink-bug population below the ET at the lowest cost. Clearly, for the level of infestation of $E$. heros assumed in the model, releases of more than 20,000 total parasitoids per hectare (number of parasitoids per release per hectare multiplied by the number of releases) may not significantly increase the efficiency in suppressing the $E$. heros population to the point of offsetting the increased cost of the strategy, which was not quantified in this study. Field studies are needed to validate these results.

Although the spacing between releases in points or strips of $T$. podisi affected the efficiency of suppressing the stink-bug population less than the number of releases and number of parasitoids per 
release per hectare, its importance cannot be underestimated. For example, the strategy of four releases of 5,000 parasitoids per hectare at points spaced $50 \mathrm{~m}$ apart resulted in a final $E$. heros population 16.6 times larger than the same strategy with a point spacing of $25 \mathrm{~m}$. Therefore, since spacings from 5 to 25 $m$ differ little in efficiency in suppressing the stink-bug population, we recommend that field studies of $T$. podisi releases use the spacing of $25 \mathrm{~m}$ for release modes in both points and strips, for more-efficient use of the parasitoids. The efficiency of the strategies regarding these two release modes was little affected by the spacings of 5,10 and $25 \mathrm{~m}$, as also observed by Bueno et al. (2020a) when comparing the release of capsules containing T. podisi pupae and the release of individual pupae in strips. This result suggests that releases can be carried out both ways, depending on the method available to the farmer or which one is more economical.

Since the mean daily dispersal capacity of $E$. heros is not known, the lower sensitivity of the model to this parameter for both the nymph and adult stages of stink bugs is desirable, due to its small impact on the results of the release strategies studied. This can be explained by the higher dispersal capacity of the parasitoid in relation to the host, so that the mean dispersal values tested did not allow the stink-bug population to move far enough from the area of occupation of $T$. podisi that significant differences would be observed in the efficiency of stink-bug population suppression. Therefore, the ability to colonize the area occupied by the $E$. heros population was more affected (and therefore dependent) by the difference between the dispersal capacity of the host and the parasitoid, using the intervals tested.

The parasitoid releases simulated here started when the arrival of $E$. heros adults in the grid was detected, not when the population reached the ET of 2 stink bugs $(\geq 0.5 \mathrm{~cm})$ per linear meter. This ET was defined based on the use of chemical control (Bueno et al. 2015), which can act directly on the population of nymphs and/or adults and effect more immediate control, compared to management with parasitoids that control the egg stage of the pest. Therefore, planning the best release time for T. podisi needs to consider the stage of the pest and the length of time required for the parasitoids released to effectively suppress the pest. Therefore, when releasing egg parasitoids, one must manage the egg population of the stink bug, to maintain it below a threshold that in the future would produce a population of nymphs and adults that would cause significant losses to the crop. Detection of the arrival of $E$. heros in the field as a criterion to initiate $T$. podisi releases is useful to suppress the first peak of eggs laid by the colonizing stink bugs and to prevent the pest population from growing, in addition to providing parasitoids that can remain in the area until harvest, if they find favorable conditions. However, field studies with T. podisiare still needed to better define the optimum time for parasitoid release (not addressed in this study) and to determine the appropriate ET for this management tactic.

Despite the importance of the computational model developed here, it important to consider the limitations and the scope of the proposed model when analyzing the results. This is a theoretical model developed from data on the biology of the parasitoid and host studied in the laboratory, with insect populations obtained from the central-south region, under controlled conditions of temperature, humidity, and photoperiod (Azambuja et al. 2013; Silva et al. 2018; Michereff et al. 2019; Possebom et al. 2020). Although stochastic, the model does not consider the action of biotic agents, such as natural enemies of 
T. podisi and E. heros, and abiotic factors, such as precipitation, fluctuations in temperature and humidity, wind speed and direction, and even the application of pesticides, which can influence the survival and fecundity of the insects and the efficiency of management using the parasitoid (Nakama and Foerster 2001; Pomari-Fernandes et al. 2018; Pazini et al. 2019; Grande et al. 2021). The effects of intra- and interspecific competition for T. podisi and E. heros were also not considered. We simulated an extremely high level of infestation to ensure that the best strategies indicated by the model can control the most diverse levels of infestation observed in soybean fields. The control stink-bug population (no release) was slightly larger than the largest populations detected by Souza et al. (2018) and Marques et al. (2019) for the same crop stage. The first population peak occurred between 30 and 40 days after stink-bug colonization, as also observed by Fonseca et al. (2014) and Souza et al. (2018), but which was later surpassed at the end of the simulation by the offspring of the second generation of stink bugs. However, this theoretical population increase at the end of the simulation is not usually observed in field populations. It depends on the duration of the crop cycle (to provide sufficient time for the stink bugs to develop and reproduce) and the intensity of stink-bug migration to alternative plants and adjacent crops during the soybean growth and ripening (Corrêa-Ferreira and Panizzi 1999), not considered in the model.

The choice of the best release strategies evaluated here was based only on their capacity to reduce the $E$. heros population throughout the simulations. However, for effective implementation in the field, it is necessary to consider the costs associated with each strategy and to test its efficiency in the field, in order to choose the strategy with the optimum cost-benefit ratio for the farmer. Furthermore, management by releasing parasitoids is only one of the control methods that comprise IPM, and it is essential to use other tactics for sustainable and efficient management of $E$. heros in soybean (Bueno et al. 2020a). Among these are conservation of its natural enemies, cultivars tolerant to stink-bug attack, and when necessary, chemical control with selective insecticides (Bueno et al. 2021). The success of biological control depends on effective monitoring of the pest population to detect its arrival in the crop and implement management tactics at the most appropriate time, according to the target stage of the biocontrol agent (Crowder 2007). These considerations aside, our study is the first to compare 128 different T. podisi release strategies in addition to a control (without release), a range of strategies that could only be compared using computational models. The release strategies recommended by our model showed a satisfactory similarity to the release strategies recommended in the literature for T. podisi, evidencing its ability to capture and faithfully reproduce general characteristics of biological systems. However, field studies using the recommendations proposed by the model are still needed for proper implementation by producers for the management of $E$. heros. Overall, our results allow the conclusion that the release strategies capable of maintaining $E$. heros population below the ET were those that released a total of at least 15,000 female parasitoids per hectare, with three to four releases of 5,000 or more adult females of $T$. podisi per hectare, at points or strips spaced $25 \mathrm{~m}$ apart.

\section{Declarations}

\section{FUNDING:}


IDW hold fellowship awarded by Coordination for the Improvement of Higher Education Personnel (Finance Code 001).

\section{CONFLICT OF INTEREST:}

The authors declare that they have no conflict of interest.

\section{CONSENT TO PUBLISH:}

All authors read and approved the manuscript.

\section{CODE AVAIABILITY:}

The computational model developed in C language is available in the Supplementary Material.

\section{AUTHOR CONTRIBUTION STATEMENT}

All authors contributed to the study conception. IDW developed the model and analyzed data. AGG and WACG helped with model development and data analysis. All authors read, collaborated in writing and approved the manuscript.

\section{AKNOWLEGMENTS}

To Coordination for the Improvement of Higher Education Personnel (CAPES), Brazil - Finance Code 001, for granting scholarships to IDW.

\section{References}

1. Azambuja R, Degrande PE, Pereira FF (2013) Comparative biology of Euschistus heros (F.) (Hemiptera: Pentatomidae) feeding on cotton and soybean reproductive structures. Neotrop Entomol 42:359-365. https://doi.org/10.1007/s13744-013-0132-6

2. Balbinot Junior AA, Procopio SO, Costa JM, Kosinski CL, Panison F, Debiasi H, Franchini JC (2015) Espaçamento reduzido e plantio cruzado associados a diferentes densidades de plantas de soja. Semina: Ciênc Agrár 36(5):2977-2986. https://doi.org/10.5433/1679-0359.2015v36n5p2977-2986

3. Bortolotto OC, Pomari-Fernandes A, Bueno RCOF, Bueno AF, Kruz YKS, Queiroz AP, Sanzovo A, Rodrigues RB (2015) The use of soybean integrated pest management in Brazil: a review. Agron Sci Biotechnol 1(1):25-32. https://doi.org/10.33158/ASB.2015v1i1p25

4. Brasil (2019) Instrução Normativa n. 25 de 4 de setembro de 2019. Acrescenta ao Anexo II da Instrução Normativa Conjunta SDA/SDC n. 2, de 12 de julho de 2013, quatro novas especificações de referência de produtos fitossanitários com uso aprovado para a agricultura orgânica. Diário Oficial [da] República Federativa do Brasil. Brasília. Seção 1:4-6

5. Bueno AF, Paula-Moraes SV, Gazzoni DL, Pomari AF (2013) Economic thresholds in soybeanintegrated pest management: old concepts, current adoption, and adequacy. Neotrop Entomol 
42:439-447. https://doi.org/10.1007/s13744-013-0167-8

6. Bueno AF, Bortolotto OC, Pomari-Fernandes A, França-Neto JB (2015) Assessment of a more conservative stink bug economic threshold for managing stink bugs in Brazilian soybean production. Crop Prot 71:132-137. https://doi.org/10.1016/j.cropro.2015.02.012

7. Bueno AF, Braz EC, Favetti BM, França-Neto JB, Silva GV (2020a) Release of the egg parasitoid Telenomus podisi to manage the Neotropical Brown Stink Bug, Euschistus heros, in soybean production. Crop Prot 137:105310. https://doi.org/10.1016/j.cropro.2020.105310

8. Bueno AF, Panizzi AR, Hunt TE, Dourado PM, Pitta RM, Gonçalves J (2021) Challenges for adoption of integrated pest management (IPM): the soybean example. Neotrop Entomol 50:5-20. https://doi.org/10.1007/s13744-020-00792-9

9. Bueno VHP, Parra JRP, Bettiol W, van Lenteren JC (2020b) Biological control in Brazil.. In: In: van Lenteren JC, Bueno VHP, Luna MG, Colmenarez YC (eds) Biological control in Latin America and the Caribbean: Its rich history and bright future. CABI International, Boston, MA, pp 78-107

10. Castellanos NL, Bueno AF, Khaddi K, Silveira EC, Rodrigues HS, Hirose E, Smagghe G, Oliveira EE (2019) The fitness and economic benefits of rearing the parasitoid Telenomus podisi under fluctuating temperature regime. Neotrop Entomol 48:934-948. https://doi.org/10.1007/s13744-01900717-1

11. Chevarria VV, Ponte EM, Jahnke SM (2013) Número de gerações de um percevejo e seu parasitoide e da severidade da ferrugem asiática em soja, simulados em cenários de clima e manejo no norte do RS. Ciênc Rural 43(4):571-578. https://doi.org/10.1590/S0103-8478201300040000

12. Corrêa-Ferreira BS (2002) Trissolcus basalis para controle de percevejos da soja.. In: In: Parra JRP, Botelho PSM, Corrêa-Ferreira BS, Bento JMS (eds) Controle biológico no Brasil: parasitoides e predadores. Manole, São Paulo, SP, pp 449-476

13. Corrêa-Ferreira BS, Azevedo J (2002) Soybean seed damage by different species of stink bugs. Agric For Entomol 4:145-150. https://doi.org/10.1046/j.1461-9563.2002.00136.x

14. Corrêa-Ferreira BS, Panizzi AR (1999) Percevejos da soja e seu manejo. EMBRAPA-CNPSo, Londrina, PR, Circular Técnica 24:1-45

15. Costa MLM, Borges M, Vilela EF (1998) Biologia reprodutiva de Euschistus heros (F.) (Heteroptera: Pentatomidae). An Soc Entomol Bras 27(4):559-568. https://doi.org/10.1590/S030180591998000400008

16. Crowder DW (2007) Impact of release rates on the effectiveness of augmentative biological control agents. J Insect Sci 7:15. https://doi.org/10.1673/031.007.1501

17. Fonseca PRB, Fernandes MG, Justiniano W, Cavada LH, Silva JAN (2014) Spatial distribution of adults and nymphs of Euschistus heros (F.) (Hemiptera: Pentatomidae) on Bt and non-Bt soybean. $J$ Agric Sci 6(6):131-142. http://dx.doi.org/10.5539/jas.v6n6p131

18. Garcia A, Cônsoli FL, Godoy WAC, Ferreira CP (2014) A mathematical approach to simulate spatiotemporal patterns of an insect-pest, the corn rootworm Diabrotica speciosa (Coleoptera: 
Chrysomelidae) in intercropping systems. Landsc Ecol 29(9):1531-1540.

https://doi.org/10.1007/s10980-014-0073-4

19. Grande MLM, Queiroz AP, Gonçalves J, Hayashida R, Ventura MU, Bueno AF (2021) Impact of environmental variables on parasitism and emergence of Trichogramma pretiosum, Telenomus remus and Telenomus podisi. Neotrop Entomol 50:605-614. https://doi.org/10.1007/s13744-02100874-2

20. Hiebeler D (2005) Spatially correlated disturbances in a locally dispersing population model. J Theor Biol 272:143-149. https://doi.org/10.1016/j.jtbi.2004.08.007

21. Lahiri S, Orr D, Cardoza JY, Sorenson C (2017) Longevity and fecundity of the egg parasitoid Telenomus podisi provided with different carbohydrate diets. Entomol Exper Appl 162:178-187. https://doi.org/10.1111/eea.12531

22. Lee SC (1979) Evaluation of Ooencyrtus submetallicus (Howard) and Trissolcus basalis (Wollaston) as egg parasites of Nezara viridula (L.). Dissertation, Louisiana State University, Baton Rouge, LA

23. Margaría CB, Loiácono MS, Lanteri AA (2009) New geographic and host records for scelionid wasps (Hymenoptera: Scelionidae) parasitoids of insect pests in South America. Zootaxa 2314:41-49. https://doi.org/10.5281/zenodo.191989

24. Marques RP, Cargnelutti Filho A, Melo AA et al (2019) Managing stink bugs on soybean fields: Insights on chemical management. J Agric Sci 11(6):225-234. https://doi.org/10.5539/jas.v11n6p225

25. Medeiros MA, Loiácono MS, Borges M, Schimidt FVG (1998) Incidência natural de parasitóides em ovos de percevejos (Hemiptera: Pentatomidae) encontrados na soja no Distrito Federal. Pesq Agropec Bras 33(8):1431-1435

26. Mendoza AC, Rocha ACP, Parra JRP (2016) Lyophilized artificial diet for rearing the Neotropical Euschistus heros (Hemiptera: Pentatomidae). J Insect Sci 16(1):1-9. https://doi.org/10.1093/jisesa/iew025

27. Michereff MFF, Borges M, Laumann RA, Daniel D, Lago CL, Blassioli-Moraes MC (2019) The influence of resistant soybean cultivars on the biological development of Euschistus heros (Hemiptera: Pentatomidae). J Plant Interact 14(1):544-551. https://doi.org/10.1080/17429145.2019.1662498

28. Moreira GRP, Becker M (1986) Mortalidade de Nezara viridula (Linnaeus, 1758) (Heteroptera: Pentatomidae) no estágio de ovo na cultura da soja: Il - parasitóides. An Soc Entomol Bras 15(2):291-308

29. Nakama PA, Foerster LA (2001) Efeito da alternância de temperaturas no desenvolvimento e emergência de Trissolcus basalis (Wollaston) e Telenomus podisi Ashmead (Hymenoptera: Scelionidae). Neotrop Entomol 30(2):269-275. https://doi.org/10.1590/S1519566X2001000200010

30. Pacheco DJP, Corrêa-Ferreira BS (2000) Parasitismo de Telenomus podisi Ashmead (Hymenoptera: Scelionidae) em populações de percevejos pragas da soja. An Soc Entomol Bras 29(2):295-302. https://doi.org/10.1590/S0301-80592000000200011 
31. Panizzi AR (2013) History and Contemporary Perspectives of the integrated pest management of soybean in Brazil. Neotrop Entomol 42:119-127. https://doi.org/10.1007/s13744-013-0111-y

32. Panizzi AR (2015) Growing problems with stink bugs (Hemiptera: Heteroptera: Pentatomidae): Species invasive to the U.S. and potential Neotropical invaders. Am Entomol 61(4):203-233. https://doi.org/10.1093/ae/tmv068

33. Panizzi AR, Corrêa-Ferreira BS (1997) Dynamics in the insect fauna adaptation to soybean in the tropics. Trends Entomol 1:71-88

34. Panizzi AR, Galileo MHM, Gastal HAO, Toledo JFF, Wild CH (1980) Dispersal of Nezara viridula and Piezodorus guildinii nymphs in soybeans. Environ Entomol 9:293-297. https://doi.org/10.1093/ee/9.3.293

35. Parra JRP (2014) Biological control in Brazil: an overview. Sci Agric 71:345-355. https://doi.org/10.1590/0103-9016-2014-0167

36. Pazini JB, Padilha AC, Cagliari D, Bueno FA, Rakes M, Zotti MJ, Martins JFS, Grützmacher AD (2019) Differential impacts of pesticides on Euschistus heros (Hem.: Pentatomidae) and its parasitoid Telenomus podisi (Hym.: Platygastridae). Sci Rep 9:6544. https://doi.org/10.1038/s41598-01942975-4

37. Peres WAA, Corrêa-Ferreira BS (2004) Methodology of mass multiplication of Telenomus podisi Ash. and Trissolcus basalis (Woll.) (Hymenoptera: Scelionidae) on eggs of Euschistus heros (Fab.) (Hemiptera: Pentatomidae). Neotrop Entomol 33(4):45762. https://doi.org/10.1590/S1519$566 \times 2004000400010$

38. Plouvier WN, Wajnberg E (2018) Improving the efficiency of augmentative biological control with arthropod natural enemies: A modeling approach. Biol Control 125:121-130. https://doi.org/10.1016/j.biocontrol.2018.05.010

39. Pomari AF, Bueno AF, Bueno RCOF, Menezes Junior AO, Fonseca ACPF (2013) Releasing number of Telenomus remus (Nixon) (Hymenoptera: Platygastridae) against Spodoptera frugiperda Smith (Lepidoptera: Noctuidae) in corn, cotton and soybean. Ciênc Rural 43(3):377-382. https://doi.org/10.1590/S0103-84782013005000013

40. Pomari-Fernandez A, Bueno AF, Bortolic SA, Favettid BM (2018) Dispersal capacity of the egg parasitoid Telenomus remus Nixon (Hymenoptera: Platygastridae) in maize and soybean crops. Biol Control 126:158-168. https://doi.org/10.1016/j.biocontrol.2018.08.009

41. Possebom T, Lucini T, Panizzi AR (2020) Stink bugs nymph and adult biology and adult preference on cultivated crop plants in the southern Brazilian Neotropics. Environ Entomol 49(1):132-140. https://doi.org/10.1093/ee/nvz142

42. Queiroz AP, Taguti EA, Bueno AF, Grande MLM, Costa CO (2017) Host preferences of Telenomus podisi (Hymenoptera: Scelionidae): Parasitism on eggs of Dichelops melacanthus, Euschistus heros, and Podisus nigrispinus (Hemiptera: Pentatomidae). Neotrop Entomol 47:543-552. https://doi.org/10.1007/s13744-017-0564-5 
43. R Development Core Team (2021) R: A language and environment for statistical computing. $R$ Foundation for Statistical Computing. Vienna, Austria

44. Ramos GR (2020) Capacidade de dispersão e parâmetros biológicos inerentes à criação massal de Telenomus podisi Ashmead (Hymenoptera: Platygastridae) para o controle de pentatomídeos-praga em soja. Dissertation, São Paulo State University Júlio de Mesquita Filho, Botucatu, SP

45. Rocha ACP (2016) Dinâmica de interações tróficas de Euschistus heros (Hemiptera: Pentatomidae) com Telenomus podisi e Trissolcus basalis (Hymenoptera: Platygastridae). Thesis, Luiz de Queiroz College of Agriculture, University of São Paulo, Piracicaba, SP

46. Sá LAN, Parra JRP, Silveira Neto S (1993) Capacidade de dispersão de Trichogramma pretiosum Riley, 1879 para controle de Helicoverpa zea (Boddie, 1850) em milho. Sci Agric 50(2):226-231. https://doi.org/10.1590/S0103-90161993000200009

47. Silva CC, Laumann RA, Blassioli MC, Pareja M, Borges M (2008) Euschistus heros mass rearing technique for the multiplication of Telenomus podisi. Pesq Agropec Bras 43(5):575-580. https://doi.org/10.1590/S0100-204X2008000500004

48. Silva GV, Bueno AF, Neves PMOJ, Favetti BM (2018) Biological characteristics and parasitism capacity of Telenomus podisi (Hymenoptera: Platygastridae) on eggs of Euschistus heros (Hemiptera: Pentatomidae). J Agric Sci 10(8):210-220. https://doi.org/10.5539/jas.v10n8p210

49. Souza LA, Barbosa JC, Grigolli JFJ, Fraga DF, Maldonado Junior W, Busoli AC (2013) Spatial distribution of Euschistus heros (F.) (Hemiptera: Pentatomidae) in soybean. Neotrop Entomol 42:412-418. https://doi.org/10.1007/s13744-013-0136-2

50. Souza LA, Barbosa JC, Aguirre-Gil OJ, Viana DL, Santos LS, Busoli AC (2018) Spatial distribution of nymphs and adults of Euschistus heros (Fabricius, 1794) (Heteroptera: Pentatomidae) in transgenic soybean cultivars of different maturing cycles. Semina: Ciênc Agrár 39(3):905-920. https://doi.org/10.5433/1679-0359.2018v39n3p905

51. Taguti EA, Gonçalves J, Bueno AF, Marchioro ST (2019) Telenomus podisi parasitism on Dichelops melacanthus and Podisus nigrispinus eggs at different temperatures. Fla Entomol 102(3):607-613. https://doi.org/10.1653/024.102.0317

52. Thomas JW (1972) Evaluation of Trissolcus basalis (Wollaston) as an egg parasite of Nezara viridula (L.). Thesis, Louisiana State University, Baton Rouge, LA

53. Tillman PG, Khrimian A, Cottrell TE, Lou X, Mizell III, Johnson RF CJ (2015) Trap cropping systems and a physical barrier for suppression of stink bugs (Hemiptera: Pentatomidae) in cotton. J Econ Entomol 108(5):2324-2334. https://doi.org/10.1093/jee/tov217

54. Torres JB, Bueno AF (2018) Conservation biological control using selective insecticides: A valuable tool for IPM. Biol Control 126:53-64. doi: 10.1016/j.biocontrol.2018.07.012

55. Torres JB, Pratissoli D, Zanuncio JC (1997) Exigências térmicas e potencial de desenvolvimento dos parasitóides Telenomus podisi Ashmead e Trissolcus brochymenae (Ashmead) em ovos do percevejo predador Podisus nigrispinus (Dallas). An Soc Entomol Bras 26(3):445-453. https://doi.org/10.1590/S0301-80591997000300006 
56. van Lenteren JC, Bolckmans K, Köhl J, Ravensberg WJ, Urbaneja A (2018) Biological control using invertebrates and microorganisms: plenty of new opportunities. Biocontrol 63:39-59. https://doi.org/10.1007/s10526-017-9801-4

57. van Roermund HJW, van Lenteren JC, Rabbinge R (1997) Biological control of greenhouse whitefly with the parasitoid Encarsia formosa on tomato: An individual-based simulation approach. Biol Control 9:25-47. https://doi.org/10.1006/bcon.1997.0512

58. Wajnberg E, Roitberg BD, Boivin G (2016) Using optimality models to improve the efficacy of parasitoids in biological control programmes. Entomol Exper Appl 158:2-16. https://doi.org/10.1111/eea.12378

59. Ward JH (1963) Hierarchical grouping to optimize an objective function. J Am Stat Assoc 58:236244. https://doi.org/10.1080/01621459.1963.10500845

60. Yeargan KV (1982) Reproductive capability and longevity of the parasitic wasps Telenomus podisi and Trissolcus euschisti. Ann Entomol Soc Am 75:181-183. https://doi.org/10.1093/aesa/75.2.181

61. Zalucki MP, Adamson D, Furlong MJ (2009) The future of IPM: whither or wither? Aust J Entomol 48:85-96. https://doi.org/10.1111/j.1440-6055.2009.00690.x

\section{Figures}


a
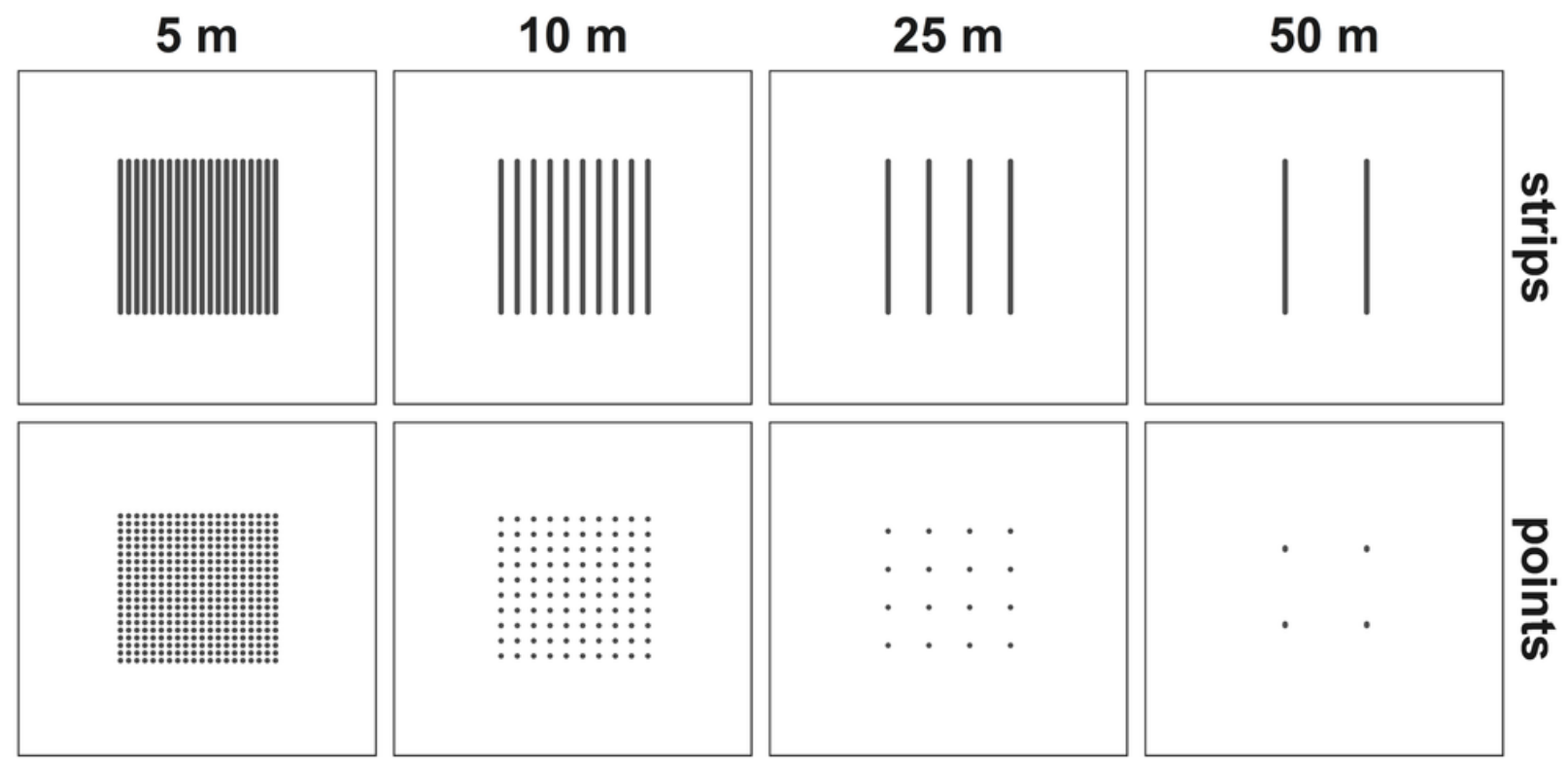

b

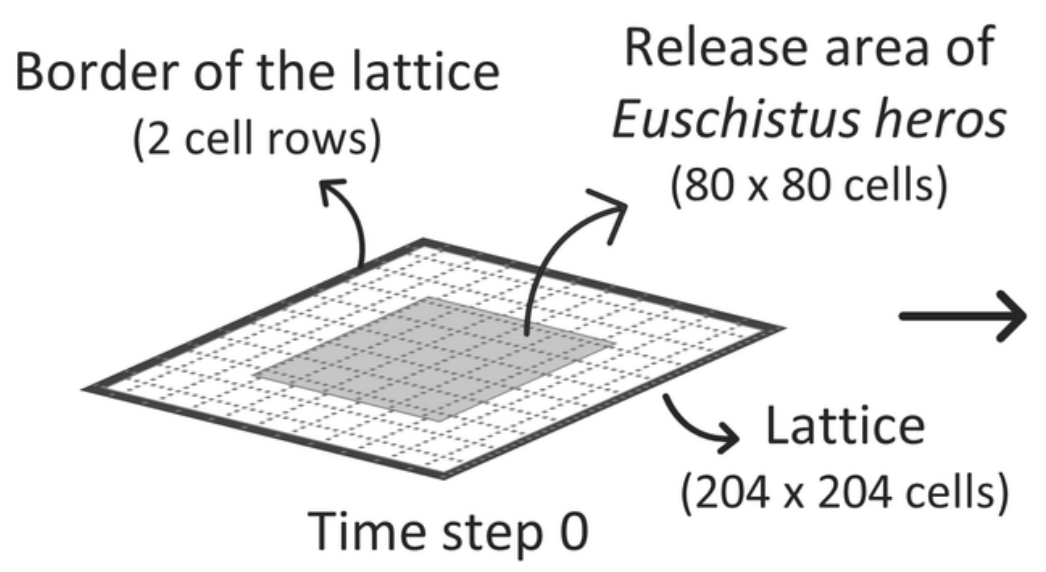

Release area of Telenomus podisi

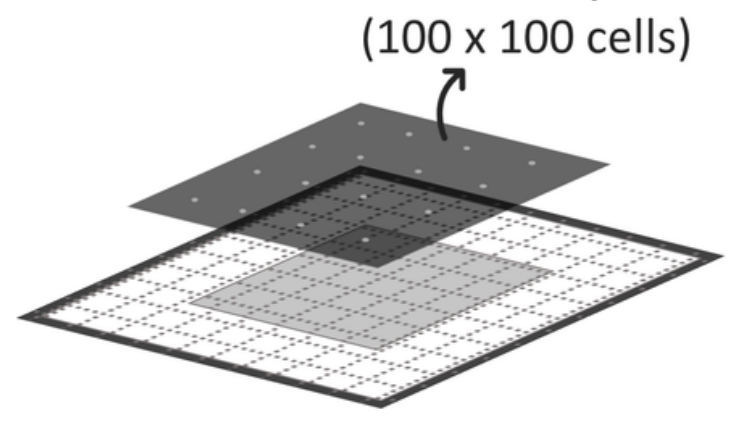

Parasitoid release time steps

Figure 1

Spatial configuration of the Telenomus podisi release points and strips as a function of the spacing between points and strips defined according to the release strategies (a). Two-dimensional representation of the grid (and its border in black), the Euschistus heros release area for colonization of the grid at time step 0 , and the virtual T. podisi release area [within which the release points (gray dots) or strips were distributed, according to the configurations shown in a] (b) 
a

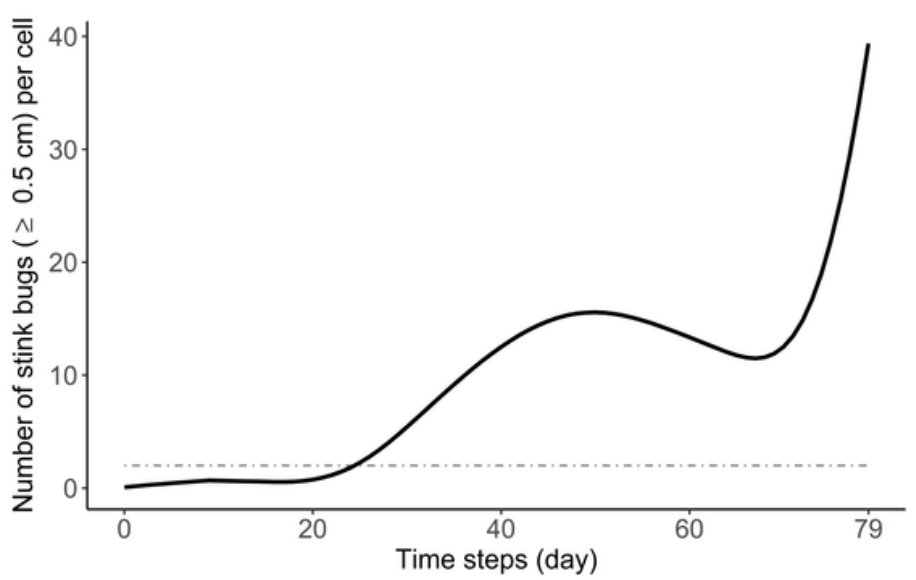

b

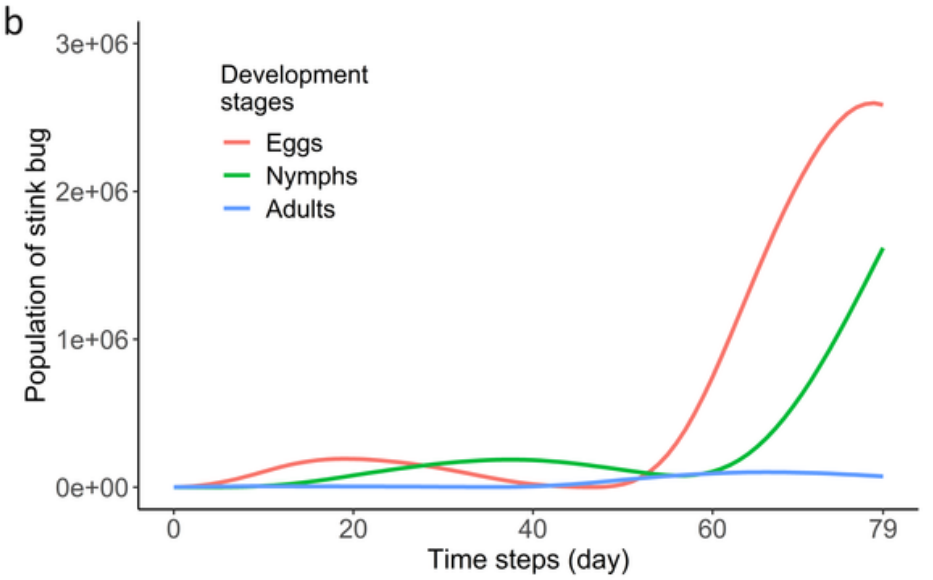

Figure 2

Mean number of stink bugs $(\geq 0.5 \mathrm{~cm}$ ) per cell of the $100 \times 100$ central cells of the grid (a), and mean total populations of eggs, nymphs, and adults (b) of Euschistus heros over 80 time steps (days) in a soybean crop when no release of Telenomus podisi is performed. Dashed line in A indicates the Economic Threshold for $E$. heros control defined for a soybean crop

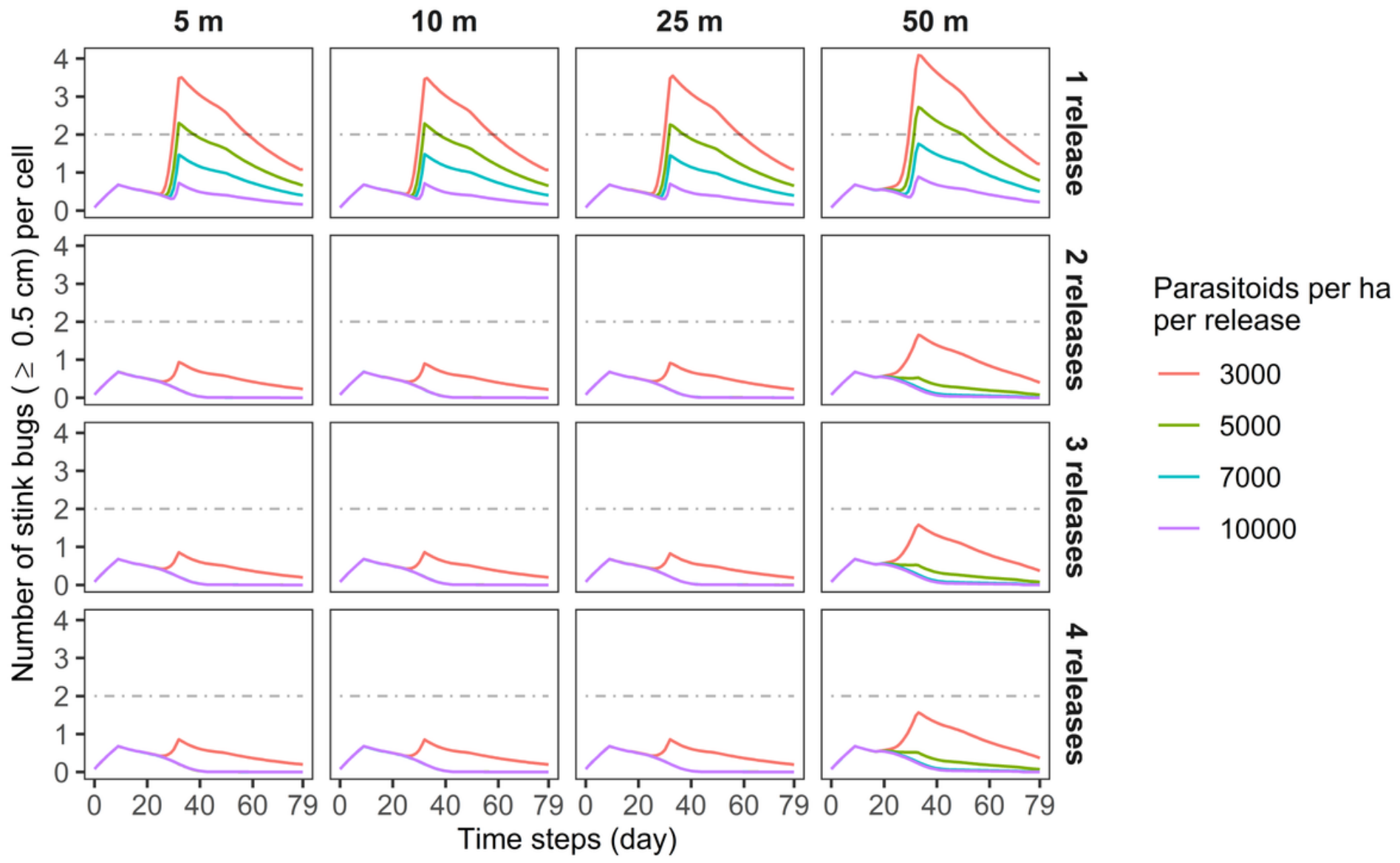

Figure 3 
Population of Euschistus heros $(\geq 0.5 \mathrm{~cm}$ ) per cell over 80 time steps as a function of the Telenomus podisi release strategies for a point release mode, considering the parasitism of the released parasitoids' offspring. Release parameters represented: spacing between points (values indicated at the top), number of releases (lines, values indicated on the right), and number of parasitoids per hectare (colors indicated in the legend). Dashed line indicates the Economic Threshold ( 2 female stink bugs $\geq 0.5 \mathrm{~cm}$ per $\mathrm{m}^{2}$ ) for E. heros control defined for a soybean crop

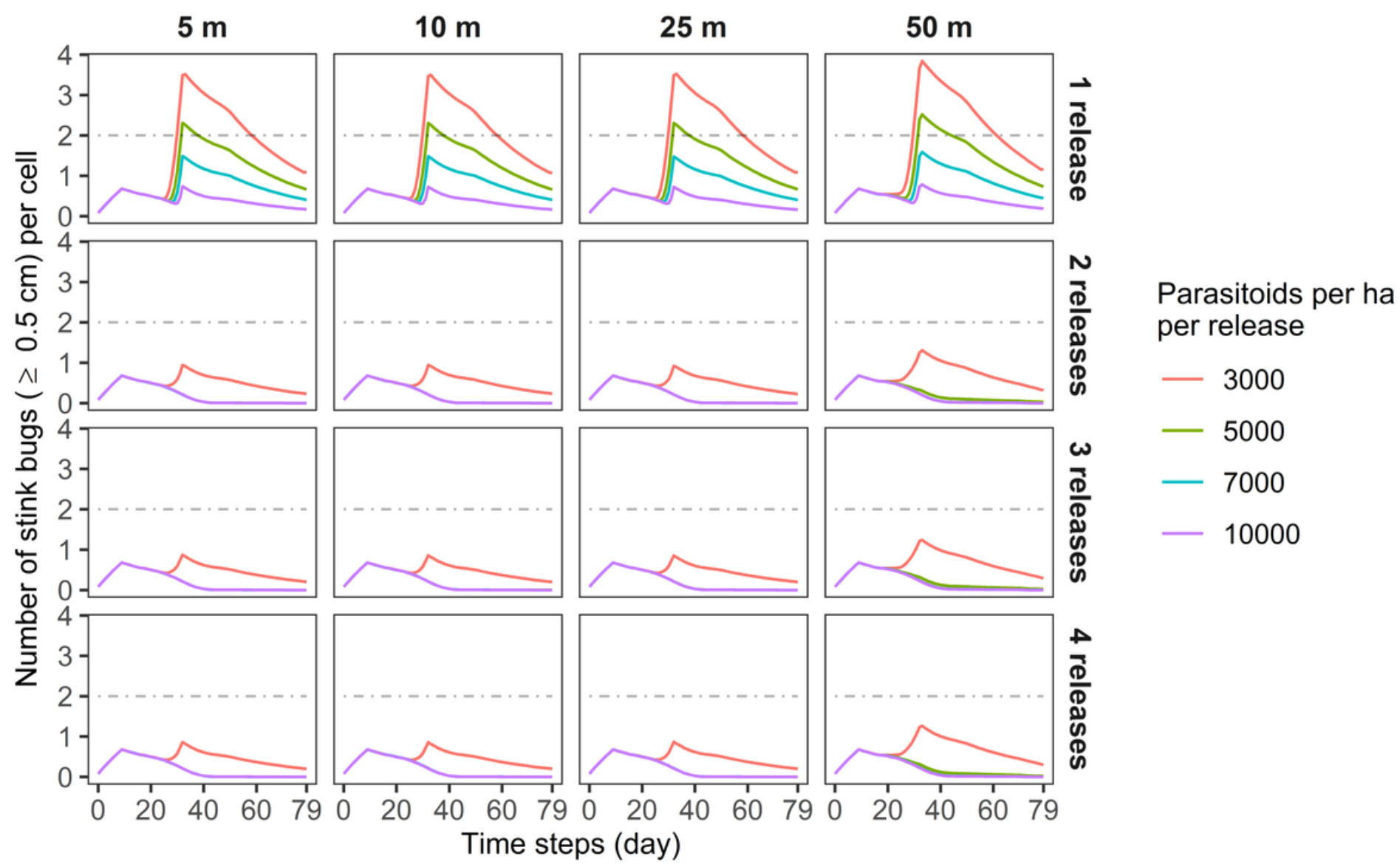

\section{Figure 4}

Population of Euschistus heros $(\geq 0.5 \mathrm{~cm}$ ) per cell over 80 time steps as a function of the Telenomus podisi release strategies for a strip release mode, considering the parasitism of the released parasitoids' offspring. Release parameters represented: spacing between strips (values indicated at the top), number of releases (lines, values indicated on the right), and number of parasitoids per hectare (colors indicated in the legend). Dashed line indicates the Economic Threshold ( 2 female stink bugs $\geq 0.5 \mathrm{~cm}$ per $\left.\mathrm{m}^{2}\right)$ for E. heros control defined for a soybean crop 


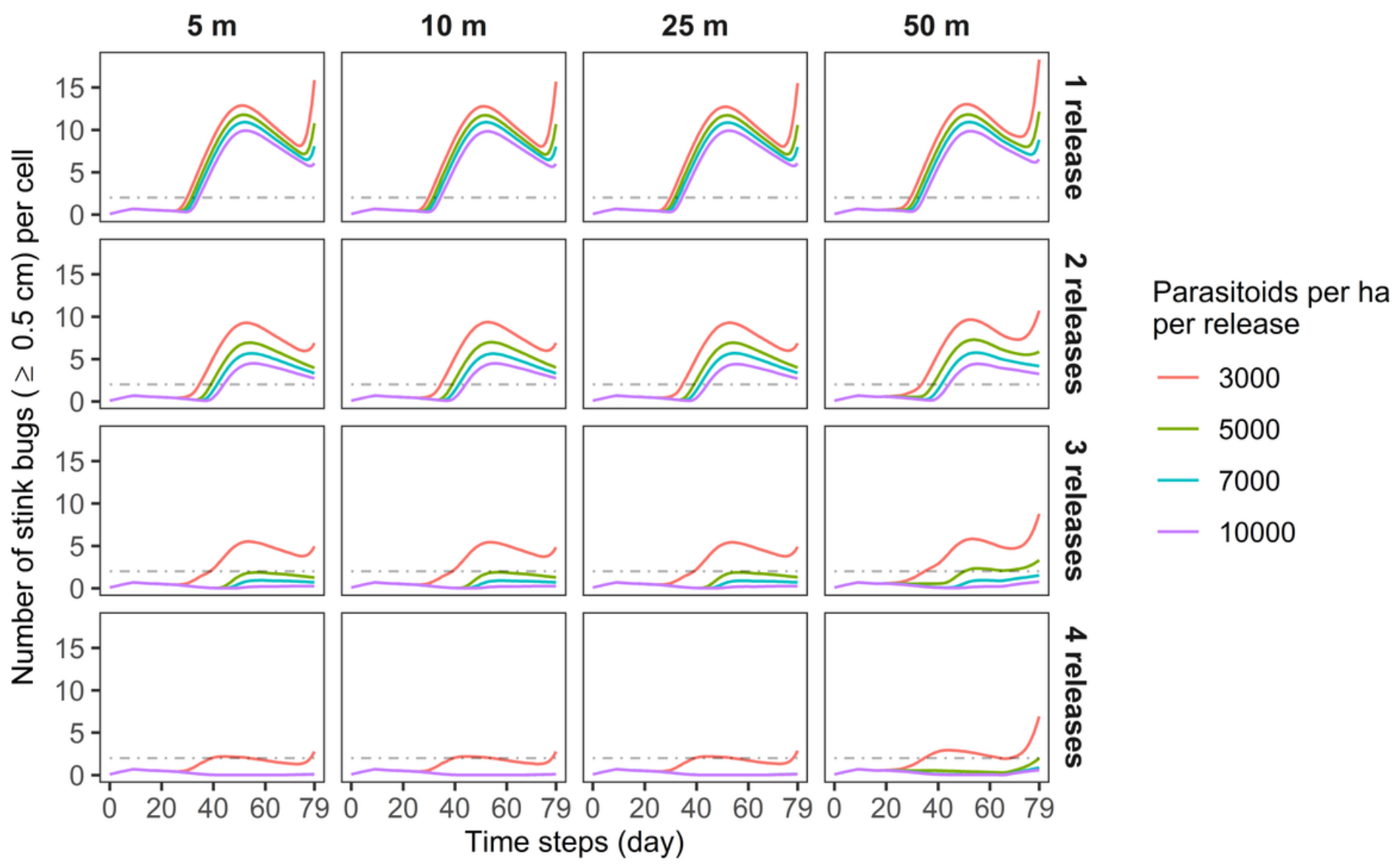

Figure 5

Population of Euschistus heros $(\geq 0.5 \mathrm{~cm}$ ) per cell over 80 time steps as a function of the Telenomus podisi release strategies for a point release mode, considering only the parasitism performed by the released females (the offspring of the parasitoids were eliminated when they emerged). Release parameters represented: spacing between points (values indicated at the top), number of releases (lines, values indicated on the right), and number of parasitoids per hectare (colors indicated in the legend). Dashed line indicates the Economic Threshold ( 2 female stink bugs $\geq 0.5 \mathrm{~cm} \mathrm{per}^{2}$ ) for $E$. heros control defined for a soybean crop 


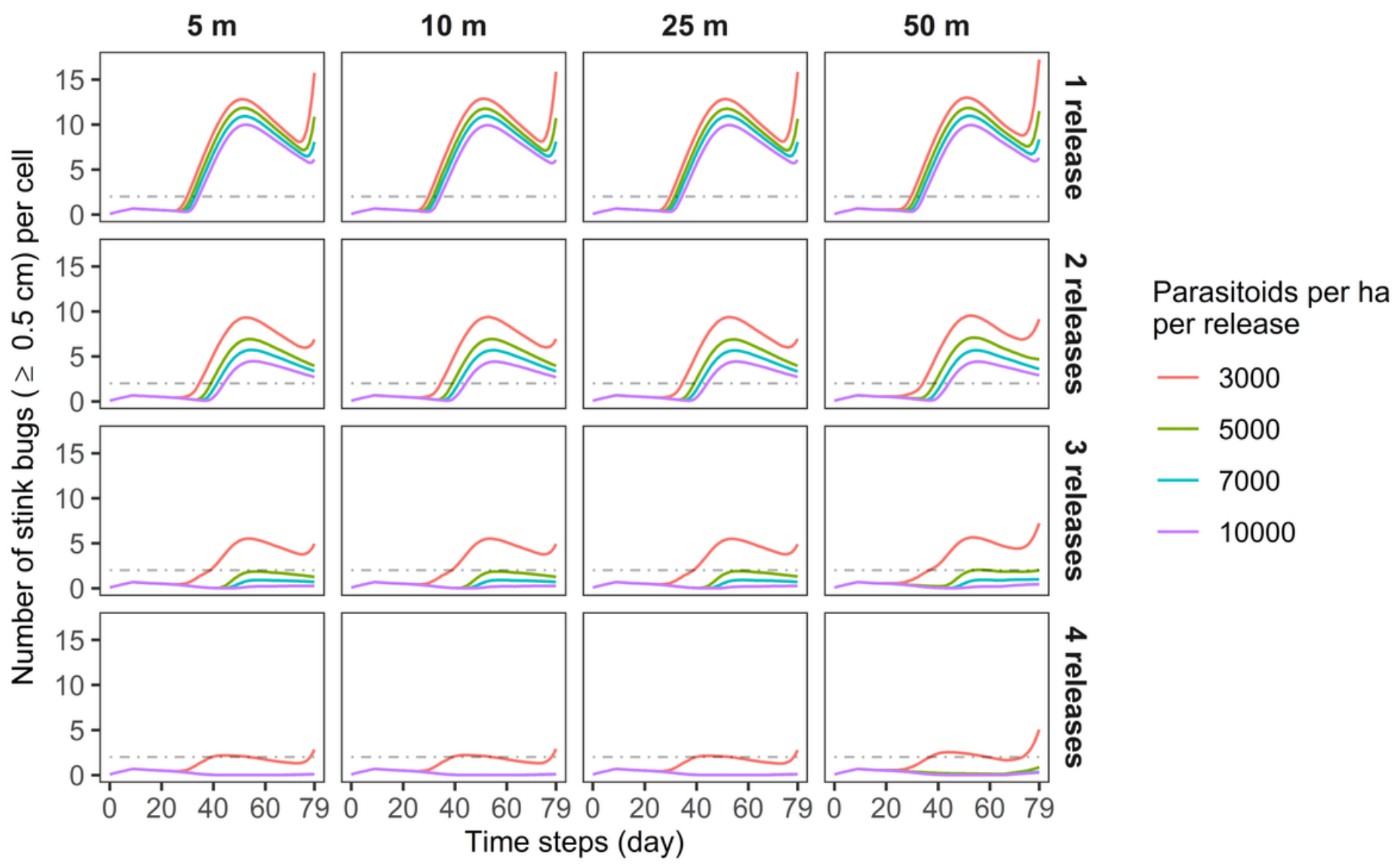

Figure 6

Population of Euschistus heros $(\geq 0.5 \mathrm{~cm}$ ) per cell over 80 time steps as a function of the Telenomus podisi release strategies for a strip release mode, considering only the parasitism performed by the released females (the offspring of the parasitoids were eliminated when they emerged). Release parameters represented: spacing between strips (values indicated at the top), number of releases (lines, values indicated on the right), and number of parasitoids per hectare (colors indicated in the legend). Dashed line indicates the Economic Threshold ( 2 female stink bugs $\geq 0.5 \mathrm{~cm}$ per $\mathrm{m}^{2}$ ) for $E$. heros control defined for a soybean crop 


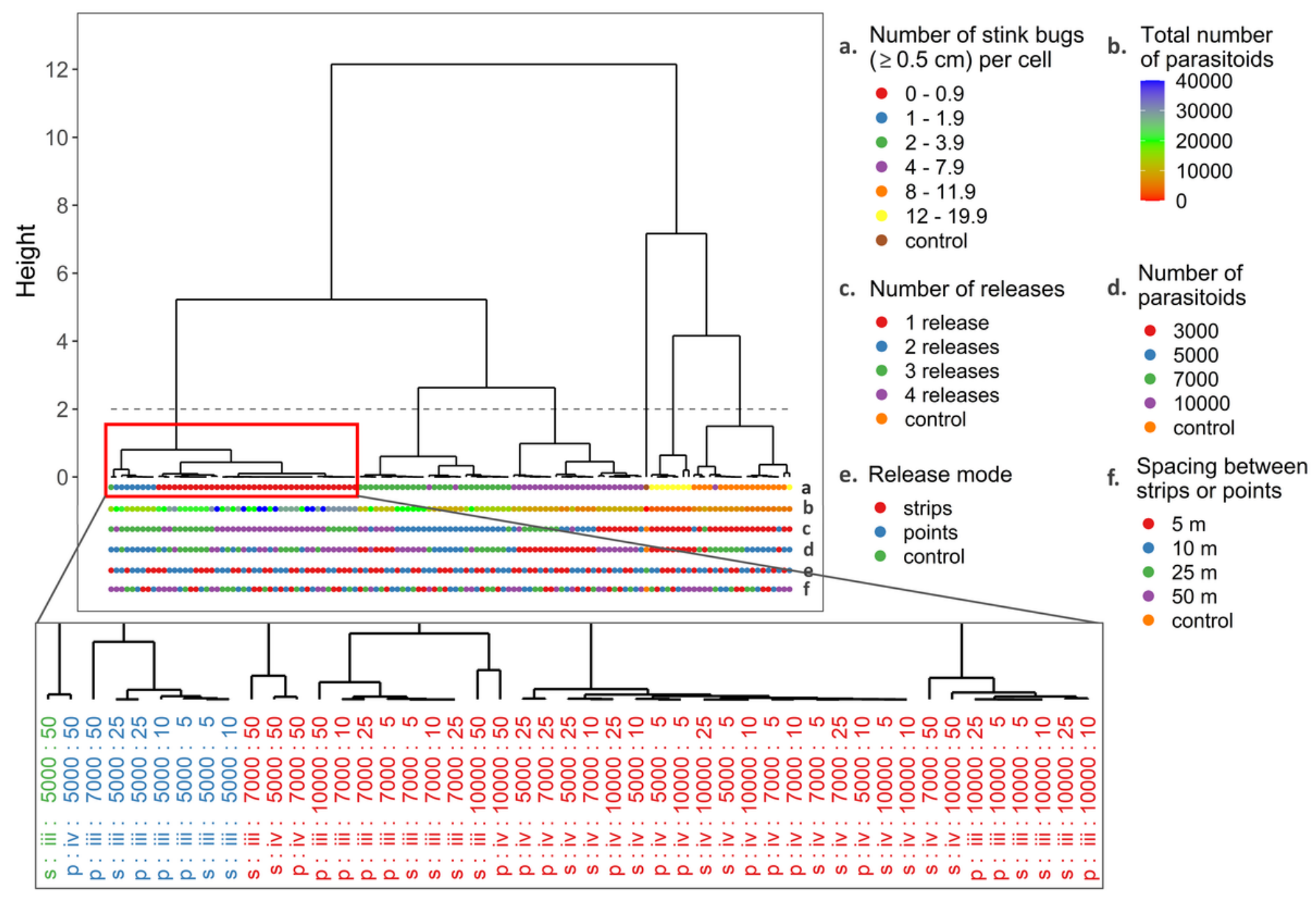

Figure 7

Hierarchical clustering of the 128 release strategies of Telenomus podisi plus the control (third branch from the right) as a function of the mean number of stink bugs $(\geq 0.5 \mathrm{~cm})$ per cell - classes of values indicated in the legend (a) in the last time step of the simulations of each strategy. Colored dots describe the configuration of each parameter (rows $b$ to $f$ ) that make up the parasitoid release strategies, whose values are given in the legends. The dashed horizontal line was arbitrarily used to separate groups of strategies that are most similar to each other. Red rectangle indicates the group of strategies that best suppressed the population of Euschistus heros, whose strategies are described in the lower box [release mode ( $\mathrm{p}$ - points; $\mathrm{s}$ - strips): number of releases: number of parasitoids per release: spacing between points or strips] 


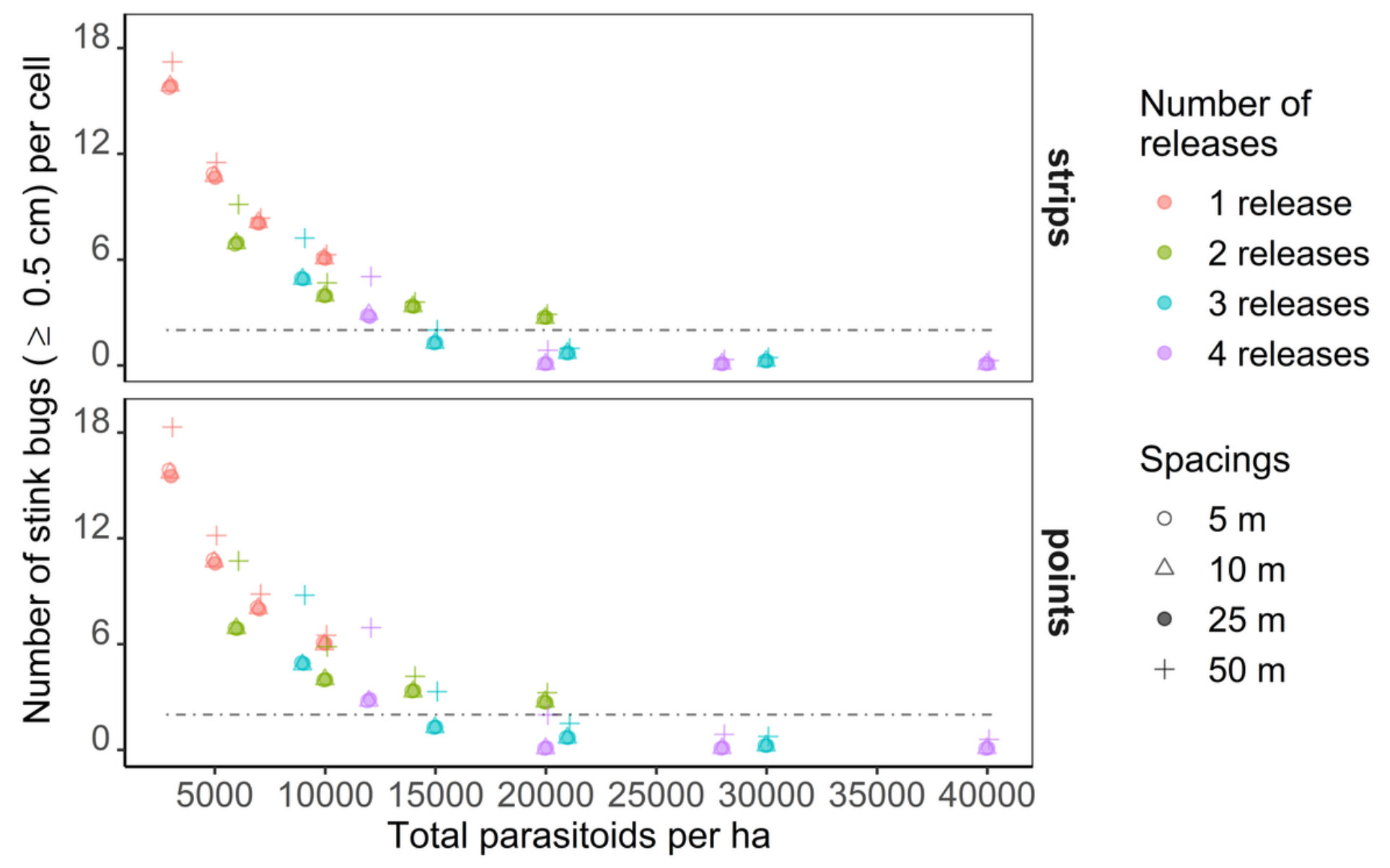

Figure 8

Number of Euschistus heros ( $\geq 0.5 \mathrm{~cm}$ ) per cell in time step 79 as a function of the total number of Telenomus podisi females released (product of the number of releases by the number of parasitoids per hectare) according to their different release strategies. Dashed line indicates the Economic Threshold (2 female stink bugs $\geq 0.5 \mathrm{~cm}$ per $\mathrm{m}^{2}$ ) for $E$. heros control defined for a soybean crop 


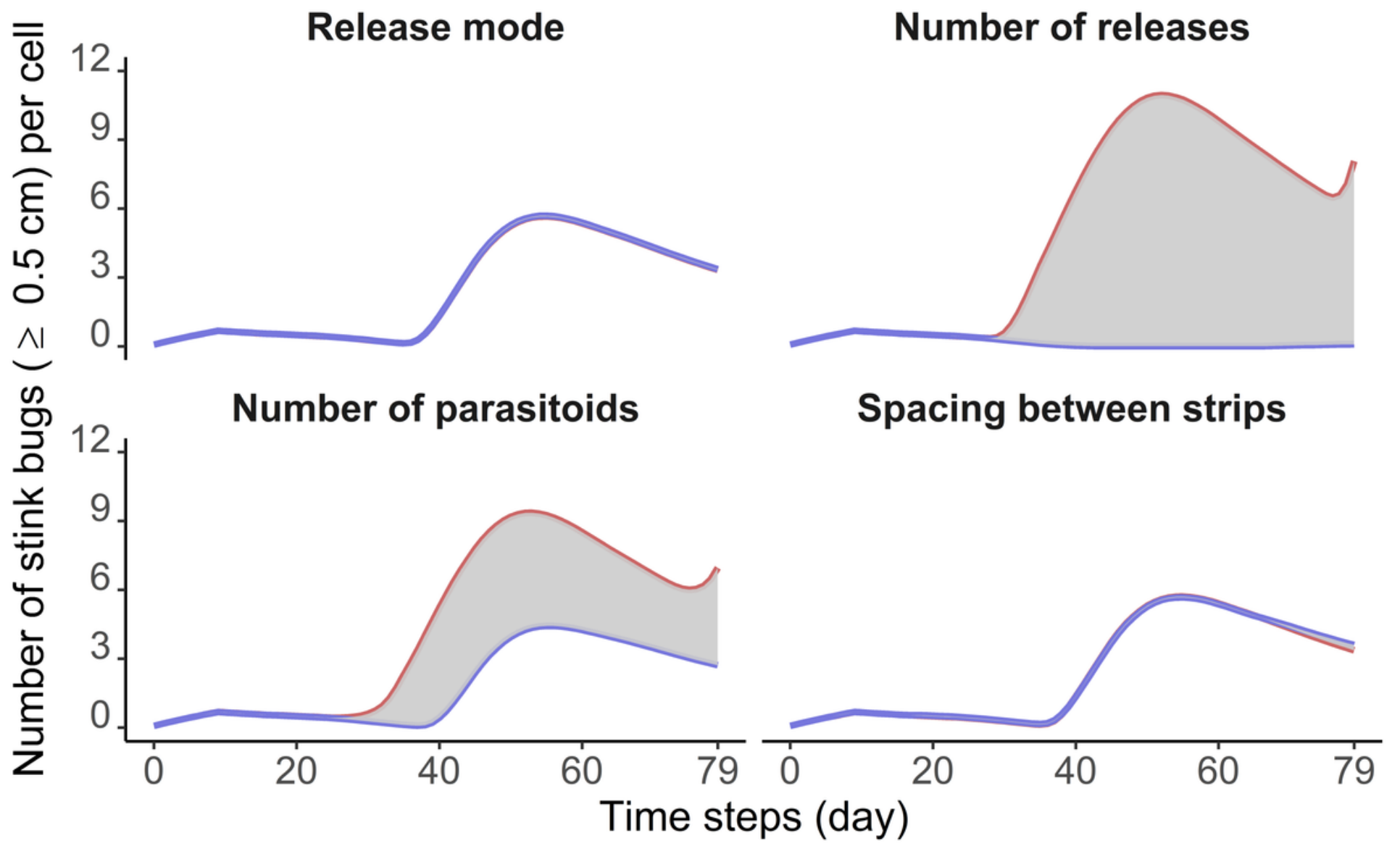

Figure 9

Model sensitivity to changes in Telenomus podisi release parameters and effects on the Euschistus heros population ( $\geq 0.5 \mathrm{~cm}$ ) per cell over 80 time steps. Red lines: point releases (top left); one release (top right); 3,000 parasitoids per hectare per release (bottom left); and 5-m spacing between strips (bottom right). Blue lines: strip release (top left); four releases (top right); 10,000 parasitoids per hectare per release (bottom left); and 50-m spacing between strips (bottom right) 


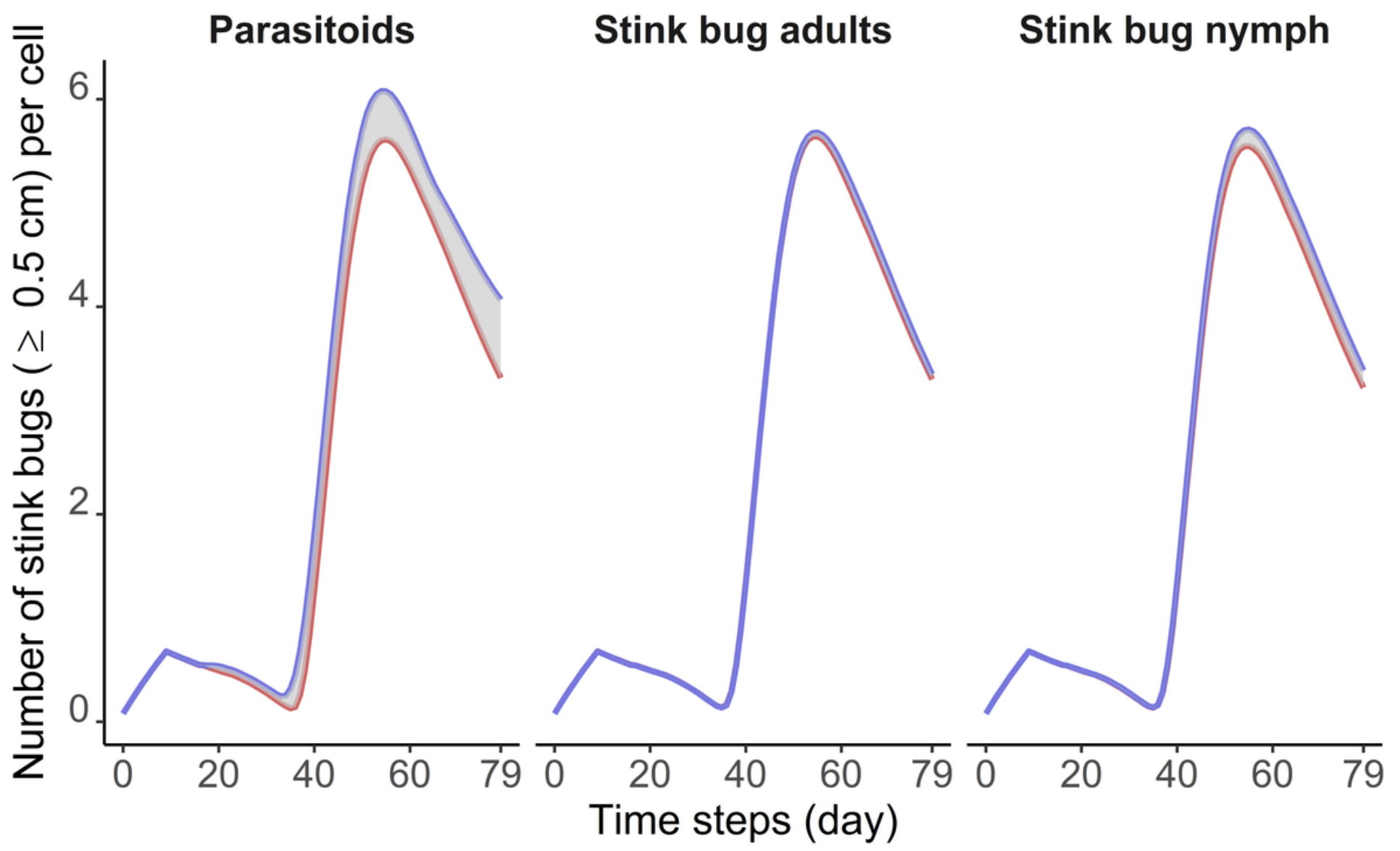

Figure 10

Model sensitivity to variation in the values of the dispersal parameters of Telenomus podisi adults (red and blue lines correspond to the dispersal radius of 16 and $4 \mathrm{~m}$, respectively), nymphs and adults of Euschistus heros (red and blue lines correspond to the dispersal capacity of 1.0 and 0.25 meters, respectively, for both stages of development) over the mean stink bug population $(\geq 0.5 \mathrm{~cm})$ per cell or $\mathrm{m}^{2}$

\section{Supplementary Files}

This is a list of supplementary files associated with this preprint. Click to download.

- ESM1.pdf

- ESM2.pdf 